\title{
SUFISM AS A TURKISH RENAISSANCE
}

\author{
${ }^{1}$ Ş.Filiz, ${ }^{2}$ L.NurpeIIS
}

\begin{abstract}
The Turkish Sufis, who created the Turkish Renaissance for centuries, should also be called Turkish philosophers. They take a human-centered religion and worldview as their main point of departure. In their humanistic approach, Islam has been adapted to Anatolian Turkish culture. Because Turkish Sufism is the practical view of Turkish philosophy in Anatolia. In addition, every Turkish philosopher has taken a philosopher, a philosophical system or a gnostic view from the ancient times and the Islamic world as a guide.

From Ahmed Yesevi to Otman Baba, the Turkish Sufism tradition combined and reinterpreted Islam with all cultures that lived in Anatolia, creating a Turkish-style world view. It is imperative to understand this four-hundred-year period in shaping the way the Turks view people, life and existence. Turkish Sufism is also the proof of the fact why the history of the Turks should be based on centuries before Islam, when viewed from the perspective of philosophy of history. Thus, historically, culturally and religiously, Turkish Sufism, Islam that started with Farabi, refers to an original Renaissance, not a transition period between the Western Renaissance that started in Italy three years later. A Republic culture that keeps faith and secularism in consensus for the two worlds has taken its spiritual inspiration from the Renaissance culture of Turkish Sufism philosophy.
\end{abstract}

Key words: Turkish Renaissance, Turkish Sufism, Philosophy, Enlightenment, Sufism, Human.

\section{Сопылық түркілік рененсанс ретінде}

Аннотация. Ғасырлар бойы түрік Ренессансын құрған түрік сопыларын да түрік философтары деп атаған жөн. Олар дінді және адамға бағытталған дүниетанымды өздерінің негізгі бастаулары ретінде қабылдайды. Өзіндік гуманистік көзқарасы бойынша ислам Анадолы түрік мәдениетіне бейімделді. Себебі түрік сопылық - Анадолыдағы түрік философиясының іс жүзіндегі көзқарасы. Сонымен қатар, әр түрік философы ежелгі дәуірден және ислам әлемінен философты, философиялық жүйені немесе гностикалық көзқарасты негізге алды. Ахмед Йассавиден бастап Отман Бабаға дейін түрік сопылық дәстүрі Анадолыда өмір сүрген барлық мәдениеттермен исламды біріктіріп, қайта түсіндіріп, түрік стиліндегі дүниетаным жасады. Осы төрт жүз жылдық кезеңді түркілердің адамдарға, өмірге және тіршілікке деген көзқарастарын қалыптастыруда түсіну қажет. Сондай-ақ, түрік сопылығы-тарих философиясы тұрғысынан қараған кезде түркілердің тарихының исламға дейінгі ғасырларға негізделуінің дәлелі. Сонымен, тарихи, мәдени және діни түрік сопылық діні, Фарабиден басталған ислам, үш жылдан кейін Италияда басталған Батыс Ренессансы арасындағы өтпелі кезеңге емес, алғашқы Ренессансқа жатады.

Сенім мен зайырлылықты екі әлемде үйлесімділікте ұстайтын республикалық мәдениет өзінің рухани шабытын түрік сопылық философиясының Ренессанс мәдениетінен алады.

түйін сөздер: түрік ренессансы, түрік сопылығы, философия, ағартушылық, сопылық, адам. 


\section{Суфизм как турецкий ренессанс}

Аннотация. Турецких суфиев, веками создававших турецкий ренессанс, тоже следует называть турецкими философами. Они берут в качестве основной отправной точки религию и мировоззрение, ориентированные на человека. В своем гуманистическом подходе ислам был адаптирован к анатолийской турецкой культуре. Потому что турецкий суфизм - это практический взгляд на турецкую философию в Анатолии. Кроме того, каждый турецкий философ взял за основу философа, философскую систему или гностический взгляд из древних времен и исламского мира.

От Ахмеда Ясави до Отмана Бабы турецкая традиция суфизма объединила и переосмыслила ислам со всеми культурами, жившими в Анатолии, создав мировоззрение в турецком стиле. Крайне важно понять этот четырехсотлетний период в формировании взглядов турок на людей, жизнь и существование. Турецкий суфизм также является доказательством того, почему история турок должна основываться на веках до ислама, если рассматривать ее с точки зрения философии истории. Таким образом, исторически, культурно и религиозно турецкий суфизм, ислам, который начался с Фараби, относится к первоначальному Ренессансу, а не к переходному периоду между западным Ренессансом, который начался в Италии три года спустя.

Республиканская культура, которая поддерживает веру и секуляризм в согласии для двух миров, черпает свое духовное вдохновение из ренессансной культуры турецкой философии суфизма.

Ключевые слова: турецкий ренессанс, турецкий суфизм, философия, просвещение, суфизм, человек.

\section{Introduction}

Although the origins of some of our philosophers are discussed in terms of attitude, manner, speaking, understanding, interpreting the world and shaping the worldview, we need to emphasize that our thinkers are Turkish philosophers. Because 12th and 16 th century. It is a true Turkish Renaissance. From Hallac-ı Mansur to Ahi Evren, Seyit Nesimi, Yunus Emre, Fuzuliye, Pir Sultan Abdal, Sheikh Bedrettin and Otman Baba, many Turkish philosophers have experienced 400 years of Turkish Renaissance has made important contributions to The Islamic world experienced a minor Renaissance between the 9 th and 12 th centuries. Since the beginning of the 9th century, the Islamic world has met with ancient philosophy. They brought many works of ancient philosophy into Arabic, Syriac and then Turkish. Ancient philosophy was revived in the Islamic world. Now, the Islamic world has revealed a brand new philosophy, a civilization perspective and a world view. The Islamic world has evolved from a god-centered, religion-centered view to a human-centered view. Literary works began to be written. Writers, poets, artists, masters of writing, scientists, philosophers have emerged. This has been called rebirth.
In the 12th century, the Islamic world faced many disasters both internally and externally. This brought some confusion. With the Seljuks, conditions such as opening up to a Renaissance again emerged. It was Turkish philosophers who perceived and evaluated these conditions in the best way. In this period, Turks started to ignite the Renaissance, which the Islamic world had lost, from Anatolia. The Anatolian Renaissance emerged with the Turkish philosophers. Turks turned this Renaissance into a human-centered Renaissance in Anatolia. The worldview of Turkish philosophers is human-centered, while they are based on inner purification, they are also based on the struggle against the evils within. On the other hand, they never put forward a passive, withdrawn, lazy understanding of Sufism.

Among the common features of the Turkish philosophers who created the Turkish Renaissance between the centuries, there is the Anatolianization of morality, human and religion. In addition, every Turkish philosopher has definitely taken a philosopher, a philosophy system or an esoteric view from the Ancient Age and the Islamic world as their guide. The Turkish Renaissance in these centuries formed the core of the establishment of the Ottoman Empire. It is our prejudices about Turkish philosophers that

$$
\begin{array}{r|r}
\text { https://adamalemijournal.com } & \mathbf{1} 13 \\
\text { ISSN 1999-5849 } & \mathbf{1}
\end{array}
$$


push us into the dark in our own history. Unfortunately, most of these prejudices are not scientifically based. It is not possible to be enlightened with prejudices that are not based on knowledge. And in this way, we are faced with a figure buried in darkness. While Westerners accept even the most ordinary people as the leaders of society, we are doing ourselves the worst disservice by always looking sideways at our own philosophers, making unrealistic and hearsay criticisms and not giving them the value they deserve. As we look at our own philosophers with such stigma and conditioning, we unfortunately face the danger of not being able to pass on our own thinkers and the many accumulations that our thinkers have inherited to our future generations.

\section{Methods}

Within the framework of this method, we determine that the period from the 12 th to the 16th centuries is the Turkish Renaissance created by Turkish Sufism. Turkish Sufism is a mystical continuation of the Islamic Renaissance. From Ahmed Yasawi, the spiritual teacher of the Turkish world, to Otman Baba, all Turkish Sufis are prominent figures of the Turkish renaissance. Human love, humanistic understanding of Islam blended with Anatolian Turkish culture and philosophical mysticism constitute the basic features of this renaissance. This understanding of renaissance, which is at peace with people, life and nature, not only Turkified Anatolia, but also inspired the Republic founded by Atatürk in 1923.

\section{Philosophical Background}

Although not in equal sections, when we divide the history of philosophy into certain parts, each period is mentioned with a new paradigm for philosophy. More precisely, every period of the history of philosophy has been marked by a dominant paradigm, problem, problem, research and investigation specific to that period. However, there are periods in the history of philosophy when it has experienced a much more significant break. In fact, these ages are turning points in human history. For example, not only Antiquity itself, but also the post-Socratic period is a turning point, a breaking age. Precisely for this reason, the IX. Age philosophy left its legacy to the Jewish, Christian and Islamic worlds. The twentieth century has not been an ordinary history, but a set of defining values of human thought and culture. The Middle Ages, with all its positive and negative aspects, began to reveal itself in this century.

This heritage, which was taken from ancient Greek philosophy, was transferred to the Islamic world with the translation of philosophical works, especially works on natural sciences, first into Syriac and then into Arabic. History of Islamic philosophy IX. With the beginning of the century XV. It is in the century. The turning point in the 600year history of Islamic philosophy is the IX. Age of Farabism [1] and X. Centuries. According to this two-century landmark [2], it is also known as the "Islamic Renaissance".

The Turkish philosopher Farabi (d. 950), who was named after the Renaissance period, also deeply influenced the philosophers after him as a rational mystic. We can say that Farabi [3] who was the "Second Teacher" after Aristotle, was the father of Turkish Humanism. Edward Said says that there is a basis in Farabi's philosophy for the existence of humanism in Islam. Farabi speaks of a universal policy that was inspired by or was a prophet at the beginning of the administration. According to him, all subjects should look to God for a thought process and ethical action. These are the tools of a society that Farabi considers to be connected beyond the borders between peoples and nations with the concept of "al-insaniye", that is, humanism [4]. Although "humanism" as an abstract concept is never mentioned in the works of the Western Renaissance [4], the concept of "al-insaniye" is used as the equivalent of humanism in the works of the Islamic Renaissance [5].

The common interest of the Italian Renaissance and the Islamic Renaissance is ethics. Cosmopolitan ideas about individualism, human dignity, and humanity are a continuation of the interest in ethics. Abu Yakup Ishaq al-Kindi (d. 873), who was de- 
emed worthy of the title of the first Islamic philosopher, took the first step towards humanism by naming the ancient sciences and philosophies "Ulumu'l-Evail", that is, "Sciences of the Ancient Ones". According to Kindi, the sciences of the ancients are the common heritage of all humanity. Islamic humanism will develop and systematize from this point on.

Farabi, "Achieving Happiness" (Tahsilu's-Saade), Christian student Yahya b. Adi (d. 974)'s "Training the Characters" (Tehzibu'l-Ahlak), Abu Hayyan Tawhidi (d. 1023)'s "Friendship" (Risale fi's-Sadaq and Sadik), Ibn Miskeveyh (d. 1030)' in "The Improvement of Characters" (Tehzibu'l-Ahlak), "The Road to High Law" by Raghib al-Isfahani (d. 11th Century), (Ez-Zeria ila Mekarimi'ş-Şeria), Clean Brothers (Ihvan-i Safa)'s Resail (Filiz, 2014) are the main classical sources of humanism in the Islamic Renaissance.

Logic and reason connect humanity and make every individual who worships rational spirit and holy power, and all people who share a rational thing, to perfection (kemal), friendship (mahabba), love (tawaddüd), compassion (tahannun), kindness (rafet) and goodness ( womb) compels. Such humanism (al-insaniye) unites all beings as one and the same community belonging to the same family. It is necessary to draw attention to the similarities with the statements of the Italian humanist Giovanni Pico della Mirandola. In 1486, when he was only 24 years old, he wrote a book on philosophical thinking as a way of self-development and a universal bond of humanity, entitled "The Word on the Dignity of Man" (Oratio Hominis Dignitate), which he emphasized as ethical [4].

Let us return to Islamic humanism. The Islamic Renaissance has made a great contribution to world civilizations. Joel L. Kraemer takes this thesis further: "Islamic translations are integral to the famous Italian Renaissance. If IX. And if it were not for the Islamic Renaissance in the X. Centuries, XII. There would be no European Renaissance in the twentieth century. Again, without this Renaissance, perhaps there would not have been an Italian Quattrocento Renaissance. Ancient Greek culture had a profound impact on the development of Islamic civilization. The Buyids Period is the period of cultural resurgence. The Islamic Renaissance is a conscious continuation of the cultural heritage of the Hellenistic and Greco-Roman era" [2]; also [6].

These humanist Islamic philosophers have attributed new human-centered meanings to the concepts of Islam, which is the paradigm of the age and to which they adhere, through translations from the Ancient Age. Kraemer brings this humanist approach together under three main headings [2].

\section{Traces of Renaıssance in Turkısh Sufılısh}

The first is individuality. In addition to being an educated, educated and useful human being, a moral definition of being is developed. As a human being who can survive with his own knowledge and manners; $\mathrm{He}$ is an individual who should strive to go beyond being "a servant who has committed himself to religion and God with everything". For example, Tawhidi's humanist attitude is worth mentioning here: Tawhidi's humanism draws our attention as a mystical humanism. Undoubtedly, he did philosophy of Sufism perhaps 217 years before Muhyiddin ibn Arabi. Tawhidi, explaining that man can reach his Lord and therefore eternal happiness by cleansing his soul, did not content himself with saying that knowledge, which plays the main role in establishing the human-God relationship, results in self-knowledge in the mystical process. It philosophically deals with how this knowledge is formed and ultimately refined in sufistic knowledge. He establishes his relationship with God as an individual. Religion is no longer an intermediary between the individual and God, with all its institutions and organizations; religiosity is built in an individual-centered manner without the need for any religious bureaucracy. Turkish Sufism, which started with Yusuf Hamadani (d. 1140), will develop this individuality with Yunus.

The second is cosmopolitanism. Baghdad is the center of many different cultures and civilizations. Muslims, Assyrians, Jews, Zoroastrians and many other members of 
religion live together. "Civilization", "urbanism" and "Medina" derived from the concept of "religion" were embodied in Baghdad.

The third is secularism. Translators and philosophers developed a rhetorical alignment with the dominant religion by finding Greek equivalents to Islamic terms and translating them into Islamic interpretations. For example, they met the shari'ah with nomos, and the Va'di sharia (i.e. the lawmaker) with nomothetes. Since concepts such as "Sunnah", "Shariah" and "religion" are purely linguistic rather than essentially religious terms, pairing them with Greek concepts is not a big deal. We can say that these and similar Arabic words have regained their secular origins thanks to these translations.

Secularization is interpreted not as the abandonment of religious belief, but as the confinement of "religion" to its "own" sphere. God is not dead, but lives in his own space, the city of God [7] .

Moreover, the humanisms of Tawhidi and Ibn Miskawayh are clearly seen in his works. Tevhidi's books and articles that have reached us today are around 22 . The work of historian and philosopher Ibn Miskeveyh called "Cavidanhired" builds a bridge between the religious life of that age and classical civilization.

Teaching etiquette-style ethics as education and entertainment provides specific guidelines for professionals. With this feature, Adab is basically secular, open and pluralistic. Clerks are trained in manners. Adab includes a broader humanistic education. Elite culture is supported [9]. Islamic humanists tried to spread education without denying the value of religion; In doing so, they sought to reduce the influence of religions in thought and practice.

The task they set themselves is not to analyze people as Muslims, but to analyze them in order to understand them. They value pure reason, they strive to develop self-confidence. They are interested in antiquity with a common language. They agreed on the ancient philosophy and sciences, which Kindi called the Sciences of the Ancients. They focused on philosophy and science on behalf of humanity without highlighting a particular religion or sect.

Although there are important differences between the universality of the unaided mind and the universality of Islam, Islamic philosophers interpret religion with a set of universal concepts and meanings that will not hinder philosophy, based on similarities (Daiber, 2003: 293-310). Similarities include the subject of education and etiquette, or paideia. Adab encompasses the educational principles and processes required to raise an elegant, kind, qualified and cultured individual. Literature supports this education as a path to wisdom.

Wisdom literature includes aphorisms, disparate evidence, stories, biographical commentaries, commentaries on natural phenomena. All of them are based on the Ancient Greek influence. The task of the philosopher is to establish philosophical analyzes, not religious truths [8]. Indeed, Islamic humanism has done just that. Islamic humanism has created the "person", that is, the person: "What is human? A person by his creation is a being with his soul, a god with his mind, wholeness together, one in multitude, mortal with his body, eternal with his self, dead with his mobility, alive with his search for perfection, lacking with his neediness, complete with being demanding, insignificant in appearance, having many news, the essence of the universe is a being. He has something of everything... Man has many news, secrets are strange. Whoever understands it, understands the universe with everything..." [10].

According to the information Tevhidi gave us, Sicistani's philosophy circle has many features in common with the Platonic Academy, headed by Marsilio Ficino. Sicistani's philosophy circle, just like Ficino's Academy, consists of an unorganized, simple and unorganized school, and a group of teachers around which various groups and professional students are clustered. More or less, it was shaped by the views of the knowledge at the beginning of the school, but it was composed of students with different ideas and interests. While private and public discussions were held, there were occasional discussi- 
ons between students and visitors at this school. This school followed programs of philosophical study in the Islamic Renaissance. The programs included a wide range of humanistic activities. As for the reasons, it is the implementation of discussion programs on a wide variety of fields and subjects such as grammar, poetry, oratory (speech), logic, philosophy, ethics, politics, physics, mathematics and metaphysics.

\section{Examples of the Leading Sufis of the Turkısh Renatsance}

Ahmed Yesevi (1093-1196), who formed the first circle of the Turkish Enlightenment and led this enlightenment, Ahi Evren (1169-1261) [11]; [12], [13] and his His teacher and father-in-law were Sheikh Evhaduddin Hamid al-Kirmani (1166-1238) [11]. We can list his contemporaries and later Turkish philosopher saints as follows: Hacı Bektaş-ı Veli (1209-1270) [14], Mevlana Celaleddin-i Rumi (1207-1273), Barak Baba (d.1318), Yunus Emre (1241-1320), Sayyid Nesimi (1370-1418), Hacı Bayram Veli (1348-1429), Shah İsmail Hatayi (1486-1524), Pir Sultan Abdal (1480-1550) [15]. Sheikh Bedreddin (1359-1420) [16], Fuzuli (1480-1556) [17], Karacaoğlan and Kul Himmet (beginning of the XVII century), dozens of Turkish philosopher saints whose names we have not yet been able to mention, here are the XI. Century-XVII. They are the names of the Turkish enlightenment that took place between the centuries, which still have not come to light properly.

We will select only Hallac-ı Mansur, Sheikh Bedreddin and Kaygusuz Abdal among these Turkish Sufi philosophers.

The Spinoza and Kierkegaard of the Turkic World

\section{Hallac-I Mansur (d. 922)}

The real name of Hallac-ı Mansur is Hüseyin. He was born in 858 in the city of Tur in the Persian province of Iran. According to Ibn Nedim, although there was a predominantly Arab population in Beyza, to which the city of Tur was connected, the population of Tur was mostly Turks. It is said that he received the title of "Hallac", that is, "the one who overturns", because he upset the mysteries in people's hearts or threw cotton. He was known by the name of his father as Hallaj-ı Mansur in Iran and the Ottomans and gained fame with this name. The people of Melâmet praised him as the "Sultan of the Melamis".

He met the famous Sufis of the period in Basra and Baghdad and joined their conversations. Among these Sufis, Sehl Tuster, Eb Hüseyin Nuri, Amr b. We can count Osman el-Mekki and Cüneyd-i Baghdadi. However, he fell out with most of these Sufis. He went to Hejaz several times for Hajj and stayed there for a while. He traveled around Ahvaz, India, Khorasan, Talekan, Maveraunnehr, Maçin, Turfan and Kashmir and gave very impressive speeches in these centers.

Hallac-i Mansur is a hafiz. He took a hafiz lesson among the Hanbalis in Wasit and became a hafiz. He took lessons from important Sufis such as Cüneyd-i Bağdadi, Amr bin Osman El Nuri and Ebu Hüseyin Nuri. It is recorded that he went on pilgrimage three times. He took lessons from Islamic scholars, generally known as Sunni, and became Sunni students. Abdurrahman Bedouin, one of the contemporary Arab philosophers, likened Hallaj-ı Mansur to Soren Kierkegaard, who died in 1855 and is considered one of the pioneers of existential philosophy.

Here, we have caught a very important clue about the Turks' perception of the world and the religion of Islam. Turks perceive the world not according to fiqh, but according to the emotionality, morality, civilization and enthusiasm of Islam. Turks perceive Islam not as a community, but as an individual. This is where his similarity with Kierkegaard comes from.

Kierkegaard speaks of an abstract individual religiosity. In other words, he tries to get rid of Christianity, then makes a divine discourse again and talks about an abstract religious individual. We can see this in Fear and Trembling and in many of his works such as Either-Or. But our Kierkegaard is Hallaj-ı Mansur.

Hallac-ı Mansur traveled to many cities, towns and settlements from the Arab, Persian and Turkish worlds; He took lessons from many scholars from every denomi- 
nation and denomination. Considering the circumstances of his time, it is clear that he was aware of very different people, places and ideas. As such, it would not be right to fit Hallaj into any religious or ideological mold. As a Turkish Sufi and scholar, he has made it his motto to see different places and to breathe rich climates of thought. This shows that he is a person of universal thought and belief. Universal thought and belief kept him away from dogmatism; It has been appreciated by people from almost all walks of life.

\section{Ahi Evren and Ahilik (Ahilik)}

His real name is Mahmud b. Ahi Evren, who is Ahmed el-Hoyi (d. 1261), is mostly known as the same person as Nasreddin Hodja, who is famous among the people for his humor, quick wit and quick response. Evren is a versatile Turkish philosopher who established the intelligence organization among Turks. Ahilik, which means generosity and industriousness, or as it is famously known, is the concrete example of the social organization of the theory-action integrity that Ahi Evren brought together in his personality. Ahi Evren is a deeper and more versatile Turkish philosopher than the famous Nasreddin Hodja profile. Ahi Evren, with his comprehensive knowledge and world of thought ranging from medicine to esoteric sciences, from folk culture to philosophical issues, has implemented the Awareness organization in line with these enlightened thoughts in his mind; He has transformed his theoretical knowledge into a practical enlightenment of business and production ethics that has become widespread at the social level. This movement, which was carried out both theoretically and practically during the Anatolian Seljuk period, is a Turkish enlightenment that can shed light on us even today. Reason and belief, humanism and Turkmen culture, business and morality, philosophy and religion, zahir and batin are in harmony in the Akik organization. Wisdom has created the Turkish interpretation of the religion of Islam and Turkish philosophy by establishing the theory-action integrity of Turkish philosophy.

"God has created man with a civilized nature. This means that Allah has created humans in need of many things such as eating, drinking, getting married, and having a home. No one can meet these needs on their own. When this is the case, many people are needed to carry out various professions such as blacksmithing and carpentry, and since blacksmithing, carpentry and all other professions and arts can be done with a set of tools and equipment, a large number of people are also needed to supply these tools and equipment. In this respect, it is inevitable to keep all branches of art necessary for people (society) alive and to direct enough people to this work. they need to be busy with art so that all the needs of the society are met" [18].

With these words, Ahi Evren established the Social Contract theory written by Jean Jacques Rousseau in 1762, exactly 462 years ago. In the Ahilik Organization, he implemented the moral-cooperation that allows people to live together in peace, without harming each other, in accordance with the rules of cooperatives, social solidarity, general morality and current law, in industrial markets. The general moral rules of Islam correspond to positive law, and the principles of life of Turks in peace with nature in Anatolia correspond to natural law. Ahi Evren fuses these two laws with the spiritual inner purification of Turkish Sufism. The external world is experienced according to the spirituality to which the purified soul is connected, and in this way, it creates both individual and social unity in the context of nature-human-divinity theory-action. The roots of the Anatolian Turkish Enlightenment, which will live today and tomorrow with the War of Independence under the leadership of Atatürk and the Republic he founded, are the work of Ahi Evren and other Turkish philosophers.

Spinoza and Husserl of the East

Sımavna Kadısıoğlu Sheıkh Bedreddın (d. 1420)

According to the statement of the historian Hammer, Simavna Kadisioğlu Sheikh Bedreddin Miladi was born in the Simav district of Kütahya in 1369. Ottoman historians of the period generally agreed with the view that this person's birthplace was Simav [19].

The first religious thought that gained 
a political identity in the Ottoman period, $\mathrm{XV}$. It is the current represented by Simavna Kadisioğlu Bedreddin at the beginning of the century. Bedreddin has an active life. He had the opportunity to meet with Timur. He became the judge of Süleyman Çelebi, son of Yıldırım Bayezid. When Bayezid's other son, Musa Çelebi, defeated his brother Süleyman Çelebi, Bedreddin took refuge in the İsfendiyaroğlu Principality because he lost his support. This principality was afraid of Çelebi Mehmet. Therefore, Bedreddin could not stay long under the auspices of İsfendiyaroğlu Principality. Çelebi Mehmet defeated Börklüce Mustafa, one of the followers of Bedreddin, who rebelled in Western Anatolia, with Bayezid Pasha. Bedreddin, who was brought to the presence of Çelebi Mehmet, who was preparing for a campaign in Serez, was executed in 1420 with the fatwa of Mevlana Haydar Novice, "his property is forbidden, his blood is halal" [20]; [21].

Sheikh Bedreddin is the Spinoza of the East and the Turkish world.

Sheikh Bedrettin has been the torch of philosophy, law, mythology and a healthy understanding of religion in Anatolia. Since his execution in 1420, he has shed light on the beauty, freedom, equality, law and justice for the Turkish people in Anatolia. Sheikh Bedrettin was a good jurist, a mystic, and a great Turkish philosopher who was also interested in medical sciences, read mythology, history and all human sciences well in his own time, but whose rights have been violated and ignored so far.

We can see Sheikh Bedreddin with different qualifications in the studies carried out depending on the sources. Some sources say that Sheikh Bedreddin was a communist. When we look at other sources, there are rumors that Sheikh Bedreddin was an apostate, an infidel and a heretic. In some sources, qualifications such as a good religious, a sincere Muslim are made. We need to clarify the distorted information about Sheikh Bedreddin, which has remained in the dark until today, and this image that is blurred with prejudices. It is possible to bring to light like Sheikh Bedreddin's own intellectual mentality, with knowledge of history, correct knowledge and treatment.
The stigmatizing words about Sheikh Bedreddin are not information. To enlighten our mind and soul also means to heal ourselves with philosophy, knowledge and historical science. If we continue to commemorate Sheikh Bedreddin with these labels, with these ideological labels, we do not have a real light of knowledge about him in the minds of each of us, but rather believe in unreal information where there are labels, ideological fights and conflicts and pretend that Sheikh Bedreddin is a victim. We will continue to monitor. This is a great darkness and sickness. Whatever the lack of knowledge, distorted ideology, prejudice, conditioning is about, it is a disease of mind and soul. We need to draw a general framework about Sheikh Bedreddin without including this unrealistic information.

Bedreddin and the people around him wanted the people to be sovereign and they fought for it. The details and tricks of this struggle appear in his work called Varidat and in the works he wrote about the philosophy of law.

The Philosopher Who Made God Speak Turkish

Kaygusuz Abdal (d. 1444)

"Türk dilin Tanrı buyurdı Cebrail

Türk dilince sölegil dur git digil

Türk dilince Cebrail"hey dur"didi

Durı gel uçmagın terkin ur didi."

After talking about Abdal Musa, we will examine his closest companion, disciple and dervish Kaygusuz Abdal. Kaygusuz Abdal is located in the tomb of Abdal Musa, in a place that was originally located without an inscription. Kaygusuz Abdal came to Tekke village from Alanya. He is the son of Alaiye Beyi. He is a very wealthy person who has all kinds of possibilities and has no worries about life. But he left all these riches and came to Elmalı Tekke village and became attached to Abdal Musa and soon became his disciple. He has been serving Abdal Musa in Tekke for 40 years. This should be seen as a great sacrifice.

Almost all of Kaygusuz Abdal's works have survived to the present day. For this reason, we have extensive information about Kaygusuz Abdal. Some of his very important works such as Dilgüşa, Dolap- 
name, Sarayname were published by the Presidency of Religious Affairs. Translated into today's Turkish and added footnotes. It is possible to know the philosophy of Kaygusuz Abdal by making use of all these sources. He has 15000 poems and 12 works. These poems are an indication of that enlightenment thought that was influenced by Abdal Musa. There are many Advices. It will be much more useful if these are examined separately, especially in terms of philosophical and religious interpretation. Kaygusuz Abdal is a great Turkish philosopher who was educated in all fields of science of his time, was well educated and provided the necessary equipment at all stages of education. To give an example of his works, his verse works; Divan, Gulistan, Mesnevi Baba Kaygusuz, Gevhername, Minbername, Budalaname, Kitab-ı Miglate, Vücudname. Mixed works in verse and prose are Sarayname and Dilgüşa. If we look at his views based on his works; First of all, the unity of the body is emphasized in almost all Turkish Sufis and philosophers who deal with the concept of unity of body. In other words, this whole universe, which is the Creator and the created, the truth and its attributes and shadow, is one. All these variations we see are the manifestations of a single absolute, right, and god in the unity of the body. Appearances have no basis. Its origins and principles are God himself. Wahdet-i-wudu specifically explains this. Not only does God talk about the unity of the universe, in fact, the reflection of this is the whole universe of existence, in which all humanity is one, and the manifestation and appearance of a single right. Therefore, unity is determined and we see that it corresponds to unity in political, social, civil, religious and philosophical sense.

If we look at the path of the sect that Kaygusuz Abdal said, it is a path without provisions, blessings, profits and rank. Today's sects have the exact opposite of these. As Kaygusuz Abdal expressed in the old times, the main way of sect is a way that does not allow any worldly conversation to settle in people's hearts because it is the way of truth. In the way of truth, food is never sought, no profit is expected, no politi- cal, economic or social interests are expected. When the opposite happens, the sect will cease to be the way to truth. Another view of Kaygusuz Abdal; Man is a contradiction that contains all kinds of contradictions in his own existence. God has created all kinds of contradictions in man. Here human existence is the existence of contradictions. It is a unity in which your desires, wishes, mind, intelligence and body contradict each other. This contradiction creates man. When Kaygusuz Abdal, who died in 1444 , says this, his existentialism does not come to mind, but 19th-20th century. In the 19th century, French philosophers or writers become the philosophers of the world when they say one word from it. This is an injustice. Kaygusuz Abdal wanted to tell how a creative being is based on the contradictions of man. It is the manifestation of a creator. In other words, since man is the manifestation of the god who created him, he has to be a creative, active, self-sacrificing creature who does not expect any benefit. God is a disinterested and resourceless being. God is an absolute right from corruption, immorality, theft. A Sufi or Kaygusuz Abdal, who is his manifestation, has to be disinterested, he has to resemble God. To resemble God means to be "creative". Being creative means using the potential of one's brain. And Kaygusuz Abdal proved this to the end by collecting all the sciences of my time.

\section{Conclusion}

In the 12th century, the Islamic world faced many disasters both internally and externally. This brought some confusion. With the Seljuks, conditions such as opening up to a Renaissance again emerged. It was Turkish philosophers who perceived and evaluated these conditions in the best way. In this period, Turks started to ignite the Renaissance, which the Islamic world had lost, from Anatolia. The Anatolian Renaissance emerged with the Turkish philosophers. Turks turned this Renaissance into a human-centered Renaissance in Anatolia. The worldview of Turkish philosophers is human-centered, while they are based on inner purification, they are 
also based on the struggle against the evils within. On the other hand, they never put forward a passive, withdrawn, lazy understanding of Sufism.

In this respect, Turkish Sufism is different. Sufi interpretation is unique to Anatolia. The philosophers of Turkish mysticism are also enlighteners. Wherever there is injustice, wherever there is oppression, wherever there is injustice and other forms of inhumanity, they have opposed this situation. They devoted themselves to justice and humanity, and since they saw man as the reflection of God, they did not hesitate to sacrifice their blood for this cause.

\section{References}

1. Filiz Ş. The Turkic Philosopher Farabi who Opened the Islamic Renaissance or the Farabism Era. - Almaty, Eurasian Journal of Religious studies, [S.I.], V. 22, n. 2, p. 60-70.

2. Kraemer J.L. Humanism in the Renaissance of Islam. BRILL, 1992. - P. 329.

3. History of Islamic Philosophy (Eds. Seyyed Hossain Nasr\&Oliver Leaman). - New York, Routledge. - 155-161 pp.

4. Kaynak Iltar E. Farabi'nin Mantık Bilimine Katkıları [Uluslararası Türk Dünyası Sosyal Bilimler Kongresi 30 Ağustos 2014 - 5 Eylül 2014]. - Tataristan/Kazan, vol.1. - 375-379 pp.

5. Daiber H. Humanism: a tradition common to both Islam and Europe // Filozofijai Drustvo, №1. - 293-310 pp.

6. Filiz Ş. İlk İslam Hümanistleri Ihvan-ı Safa Topluluğu ve İnsan Felsefesi. - İstanbul, Bilim
\&Ütopya. - 20-60 pp. (in Turkish).

7. Goody J. Tarih Hırsızlığı (Çev. G.Ç. Güven). - İstanbul, Türkiye İş Bankası Kültür, 2019. - 285 p. (in Turkish).

9. Tawhidi E.H. Al-Mukabasat (Thk. Hasan es-Sandubi), al-Matbaa al-Rahmaniya. - Beirut, 1929. - 372 p. (in Arabic).

10. Bayram M. Şeyh Evhadüddin Hamid el-Kirmani ve Menakıbnamesi. - İstanbul, Kardelen. - 204 p. (in Turkish).

11. Ahi Evren. "İmanın Boyutları". (Çev.: Mikail Bayram). - İstanbul, NKM. - 15-35 pp. (in Turkish).

12. Sütççüoğlu O. Ahi Evran; İsmi ve Menkıbesi Hakkında Anlam ve Köken Sorunları [Uluslararası Bilgeler Zirvesi Sempozyumu 2628 Mayıs]. - Eskişehir, Osman Gazi Üniversitesi. -1-10 pp.

13. Filiz Ş. İlk Dönem Bektaşilik ve Hacı Bektaş Veli'nin Fikir Yapısı. - Ankara: [Türk Kültürü ve Hacı Bektaş Veli'nin Fikir Dünyası]. Nu-(3), 1-7 pp.

14. Yağ Cı Ö. Pir Sultan Abdal. Cumhuriyet Kitapları. - İstanbul, 2011. - 5-15 pp. (in Turkish).

15. Sheikh Bedreddin, Varidat (Hazırlayan: İ. Z. Eyüboğlu). - İstanbul, Derin, 2014. -40-65 pp. (in Turkish).

16. Yüksel M. Simavna Kadısıoğlu Şeyh Bedreddin. - İstanbul, Yarın, 2010. - P. 205. (in Turkish).

17. Bayram M. Fatma Bacl ve Bacıyan-ı Rum Anadolu Bacılar Teşkilatı. - Çizgi, Konya. - 57-58 pp. (in Turkish).

18. Şerafeddin M. Simavna kadısıoğlu Şeyh Bedreddin Simavi. - İstanbul, 1924. - P. 5. (in Turkish).

19. İslam Ansiklopedisi. - İstanbul, MEB, 1961.

20. Yurdaydın H.G. İslam Tarihi Dersleri. - Ankara, Ankara Üniversitesi, 1924. - P. 5. (in Turkish).

\section{INFORMATION ABOUT AUTHORS}

Şahin Filiz

Laziza Nurpeiis

Шахин Филиз

Лазиза Нұрпейіс

Шахин Филиз

Лазиза Нурпеис
Professor, PhD, Akdeniz Universitesi, Antaly, Turkiye, sfiliz@akdeniz.edu.tr, karabagsahin@gmail.com. ORCID ID:0000-0002-4249-22-21

PhD Student, University of Sakarya, Turkiye, aruana84@gmail.com. ORCID ID:0000-0002-2564-8888

профессор, PhD, Ақтеңіз университеті, Анталия, Түркия, sfiliz@akdeniz. edu.tr, karabagsahin@gmail.com. ORCID ID:0000-0002-4249-22-21

докторант, Сакария университеті, Сердиван, Түркия, aruana84@gmail. com. ORCID ID:0000-0002-2564-8888

профессор, PhD, университет Акдениз, Анталия, Турция, sfiliz@akdeniz. edu.tr, karabagsahin@gmail.com. ORCID ID:0000-0002-4249-22-21

докторант, университет Сакария, Сердиван, Турция, aruana84@gmail. com. ORCID ID:0000-0002-2564-8888 